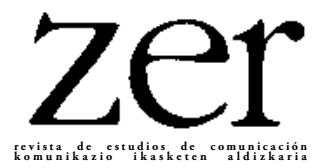

\title{
Communicative differences between emergent and traditional parties: An analysis of Facebook posts from Spain's 2015 general election campaign
}

\author{
Alderdi berrien eta tradizionalen arteko komunikazio-ezberdintasunak: \\ Facebooken 2015eko kanpainan argitaratutako mezuen analisia \\ Las diferencias comunicativas de los partidos \\ emergentes y tradicionales: análisis de los mensajes \\ de Facebook publicados durante la campaña de 2015
}

Vicente Fenoll^, Lorena Cano-Orón

Universitat de Valencia

\begin{abstract}
Social media has revolutionized political communication. It offers political parties a mass communication channel that lets them customize and create direct communication with citizens. This study analyses the posts of the main Spanish political parties on their Facebook pages during the 2015 general elections campaign. We quantitatively analyse the parties' frequency of publication on this social network and the content of their messages through a computerized content analysis. The results indicate that traditional and emergent parties manage their Facebook pages in distinct ways.
\end{abstract}

KEYWORDS: Electoral campaigns; political communication; Facebook, new parties, computer-assisted content analysis.

RESUMEN: Las redes sociales han supuesto una revolución para la comunicación politica, posibilita a los partidos tener un canal de comunicación masivo con capacidad de personalizar y crear una comunicación directa con los ciudadanos. Este estudio analiza las publicaciones de los principales partidos politicos españoles en Facebook durante la campaña de las elecciones de 2015. Desde una perspectiva cuantitativa, comparamos la frecuencia de publicación y el contenido de los mensajes a través de un análisis computarizado. Los resultados señalan que existen diferencias entre partidos tradicionales y emergentes en la gestión de las páginas de Facebook.

PALABRAS CLAVE: Campañas electorales; comunicación política; Facebook; nuevos partidos; análisis de contenido computarizado.

* Corresponding author: Vicente Fenoll. Universitat de València. Facultad de Filología, Traducción y Comunicación. Departamento de Teoría de los Lenguajes y Ciencias de la Comunicación. Avenida Blasco Ibañez, 32. 46010 Valencia - vicente.fenoll@uv.es - http://orcid. org/0000-0002-5851-4237

How to cite: Fenoll, Vicente; Cano-Orón, Lorena (2019). "Communicative differences between emergent and traditional parties: An analysis of Facebook posts from Spain's 2015 general election campaign»; Zer, 24(46), 37-51. (https://doi.org/10.1387/zer.20225).

Received: 20 september, 2018; Accepted: 29 november, 2018.

ISSN 1137-1102 - eISSN 1989-631X / (C) 2019 UPV/EHU

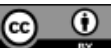

This work is under a license

Creative Commons Atribución 4.0 Internacional 


\section{Introduction}

The Internet and social networks represent an unprecedented communication phenomenon. In terms of political communication, they have created not only a new space for interacting with and consuming content, but also a digital public sphere that allows people to publish information and opinions instantaneously and globally. As Dader (2017) points out, in the electoral processes it has gone from the media monopoly to the digital contest. The space held by social networks tends to involve people who are not interested enough in politics to consume information about it. Rather, they are accidentally exposed to such content (Valeriani \& Vaccari, 2015).

Current political communication strategies cannot be understood without their digital component, as politicians are fully aware of today's hybrid strategies (CaseroRipollés, Feenstra, \& Tormey, 2016). Since the 2008 U.S. Elections, considered the beginning of political communication on social media, Facebook and Twitter have gone from being a complementary tool used only by a few candidates to a habitual communication instrument used by nearly every party (Alashri et al., 2016). The two platforms have even replaced blogs as the preferred online channel for political messages (Gamir, 2016; Gamir, Cano-Orón, \& Calvo, 2017).

Although offline communication is better at mobilizing people, social network campaigns play a key role in encouraging participation and reaching younger audiences (Aldrich et al., 2016). Having a presence on social networks is important not only because of the large numbers and demographic diversity of people who use them (Alashri et al., 2016), or because men and women use them equally (Bode, 2015), but also because they are the only way to connect with specific audiences. Facebook is one of the leading platforms for digital campaigns, precisely because its characteristics and tools encourage user participation (Williams \& Gulati, 2009). As Vaccari and Valeriani point out:

Social media have become central hubs in contemporary flows of political communication across western democracies. By contrast, political parties, one of the key institutions of representative democracy, are facing legitimacy and organizational crises (2016: 294).

Consequently, digital communication management and the image it is used to create on social networks is of vital importance to political parties. Unlike those on web pages, messages published on platforms like Twitter and Facebook lead to a much more dynamic and flexible conversation. This conversation helps create a specific identity for the account holder (Levonian, 2016). In this way, the media cease to play the role of intermediaries. Nowadays, opinion leaders stay tuned to the candidates' and parties' updates to access information immediately and more directly. 
Some studies indicate that social networks activity is a generational phenomenon: younger candidates post more and older candidates, less (Fenoll, García-Ull, \& Rodríguez-Ballesteros, 2016). Larsson and Kalsnes (2014) suggested that social networks activity represents a greater opportunity for new politicians than for those already in power. Indeed, they confirmed that high-ranking politicians tend to have largely inactive social media accounts, while those in the middle of their career tend to maintain more active accounts. This is because the goal of online communication is to persuade and mobilize the electorate, with little attention paid to policy debate (Koc-Michalska, Lilleker, Smith, \& Weissmann, 2016). On the same token, Larsson (2016) explained that online political activity increases during election campaigns.

In Spain, interaction typically takes place among individual social networks users, and, in most cases, there is little to no dialogue between the parties and the electorate (Koc-Michalska et al., 2016; de Sá, Araújo, \& de Oliveira, 2016). Despite the bidirectionality and permanent contact social networks allow for, social media users tend not to participate in the conversations that arise from their posts (Harode-Rosario, Sáez-Martín, \& Caba-Pérez, 2016; Zamora \& Zurutuza, 2014).

Indeed, the parties use digital resources following hierarchical and unidirectional criteria (Vaccari, 2013). Nitschke, Donges, \& Schade (2016) analyzed the type of content published in online conversations and detected that the traditional political parties use social networks to lead people to other party-created, online content, that is, not to encourage debate but to market themselves. Nevertheless, newer parties link to a greater variety of sources and encourage an exchange of ideas and perspectives (Nitschke, Donges, \& Schade, 2016).

López-García (2016) detected the same differences on Twitter during Spain's 2015 General Elections campaign. Whereas the traditional parties published specific policy proposals, the new parties focused on using emotion to mobilize the electorate. Even though social networks offer a bidirectional channel for constant communication with the citizenry, neither the elected representatives nor the major parties engage in meaningful dialogue with social networks users through their online publications, whether on Twitter (Alonso-Muñoz, Marcos-García, \& Casero-Ripollés, 2016; Alonso-Muñoz, Miquel-Segarra, \& Casero-Ripollés, 2016) or Facebook (Valera, Sampietro, \& Fenoll, 2017), a tendency observed in Western European (Vaccari, 2013) and Latin American democracies (Muñiz et al., 2016).

Party differences in the use of communication technology cannot be explained by national or party characteristics, but rather by the individual choices of the parties' strategists, who make decisions based on their evaluation of the tools' utility (Koc-Michalska et al., 2016). Indeed, in their longitudinal study of several EU countries from 2009 to 2014, the researchers confirmed that "parties do not use the full potential that the architecture of the web is offering" (2016:16). Differences in 
how the parties use social networks are related to their representation in government (Larsson, 2016; Rúas-Araújo, Puentes-Rivera, \& Míguez-González, 2016). That is, parties with more representatives in parliament worry less about social networks than parties in the minority. Thus, the smaller parties must make as much noise as possible on social media to disrupt the established media logic. This can be applied to Spain in terms of Podemos and Ciudadanos.

\section{Spain's 2015 General Elections}

Spain's 2015 General Elections sparked the country's interest due to the emergence of two new parties (the progressive Podemos and the liberal Ciudadanos) capable of affecting the formation of government. They are also the only elections in which Podemos participates in the campaign alone, since in 2016 it was in coalition. Thus, in contrast with the left-right dichotomy that characterized the two-party system represented by the country's traditional political parties - the conservative People's Party (PP) and the social-democratic Spanish Socialist Workers' Party (PSOE)-, there arose a new distribution of seats in parliament revolving around the parties' institutional history. In the Twitter campaign, we detected differences not between ideologies but rather between the logics of the new and old party leadership (López García, 2016). Whereas the new parties posted content geared towards using emotion to mobilize the electorate, the traditional parties published their campaign platforms' specific proposals. On the same token, Sampietro and Valera (2015) confirmed that during the 2014 European Elections, Podemos's Facebook discourse was based on the marked use of positive emotions and the first-person plural pronoun, a feature that distinguished it from other parties. This coincides with the results of international studies, such as that of Nitschke, Donges, and Schade (2014), which indicate that, on Facebook, old and new political organizations communicate in distinct ways.

Regarding Facebook campaigning, Gamir et al. (2017) discussed how, although the left-wing Podemos had more politicians with active accounts during campaign season, the politicians of the conservative People's Party were the most prolific posters. Nonetheless, in terms of candidates for prime minister, Pablo Iglesias published more posts than Pedro Sánchez, Albert Rivera, and Mariano Rajoy, respectively. On another note, Puentes-Rivera, Rúas-Araújo, and DapenaGonzález (2017) detected politicians no longer post the same way. Whereas they used to rely mostly on text, visual content is now predominant.

This study analyses how the most-voted political parties in Spain's 2015 General Elections used Facebook. In particular, we aim to detect the differences among each party's communicative strategy, focusing on the logics of new and old parties and examining in greater detail the characteristics detected in previous studies. In keeping with the theoretical framework, we propose the following hypothesis: 
H: Spanish political parties use of Facebook differs depending on how long they have been in existence.

To accept or reject this hypothesis, we will attempt to answer the following research questions:

RQ1: Do the parties' politicians interact with citizens on Facebook to differing degrees?

RQ2: Do the parties address different subject matter in their Facebook posts?

RQ3: Does the emotional weight of the parties' Facebook posts differ?

RQ4: Do the parties use the first-person plural form of verbs to differing degrees in their Facebook posts?

\section{Methodology}

To answer the research questions, we examined the Facebook posts made during Spain's 2015 General Elections campaign by the top four Spanish political parties, namely, PP, PSOE, Podemos, and Ciudadanos.

To compile the corpus, we used FacePager (Keyling \& Jünger, 2013) to download the posts and comments made on Facebook pages. We collected 535 posts, 8 comments, and 129 responses published on Facebook by the four political parties during the election campaign. We defined post as the parties' original publications and comment as the parties' messages in response to the original post. We defined response as the parties' comments in response to comments made by other users.

The study employs various quantitative analysis techniques to answer the research questions. To answer RQ1, we analysed the parties' post frequency and their level of interaction. After creating contingency tables and applying the Chi-square test, we determined which differences between frequencies were statistically significant.

To answer RQ2, we performed a quantitative content analysis using WordStat (Provalis Research, 2017), which several studies in the field of social networks have already used (Al-Rawi, 2017; Bruns \& Burgess, 2012; Conway, Kenski \& Wang, 2015; Davalos et al., 2015; Groshek \& Al-Rawi, 2013). The software allowed us to count the number of key words used and to group posts based on the similarity of their subject matter through a hierarchical cluster analysis for each party. To determine the degree of co-occurrence proximity, we calculated the Jaccard coefficient (J), which compares the frequency at which two words appear together in the same comment with the frequency at which they appear in isolation (Tan, Steinback, \& Kumar, 2006). Thus, a value close to one indicates that the words appear together in every instance, whereas a value close to zero indicates that they never appear together. 
To answer RQ3 and RQ4, we used the Spanish-language version of the LIWC dictionary (Pennebaker et al., 2015) to measure the frequency of words that appear in posts from distinct categories. For RQ3, we used emotional categories (negative emotions and positive emotions), whereas in RQ4, we quantified the words related to the first-person plural category (we, us, our, etc.). Researchers have used this program in studies on emotion analysis (Bae \& Lee, 2012; Caton, Hall, \& Weinhardt, 2015; Stieglitz \& Dang-Xuan, 2012; Tumasjan et al., 2010), as well as analyses of the linguistic patterns of discourse (Lin \& Qiu, 2013; Rúas-Araújo, Puentes-Rivera, \& Míguez-González, 2016; Fernández-Cabana, Rúas-Araújo, \& Alves-Pérez, 2014). To identify any differences among the parties' discourses, we performed a one-way ANOVA test in which we established the dictionary's three categories as the independent variables. When the homoscedasticity requirement was met, we applied Scheffe's post hoc test, whereas when variances were not homogeneous we used the Games-Howell test.

\section{Results}

To answer RQ1, we examined the 672 posts and responses published by the four parties during the election campaign. Table 1 shows the absolute frequency, percentage, and standardized residuals for each type of message (post, comment, response).

\section{TABLE 1}

Absolute and relative frequencies of parties' posts, comments on posts, and responses to users ${ }^{\star}$

\begin{tabular}{|c|c|c|c|c|c|c|c|}
\hline & \multicolumn{4}{|c|}{ Party } & \multirow{2}{*}{ Total } \\
\hline & & & PP & PSOE & Podemos & Ciudadanos & \\
\hline \multirow{9}{*}{ Level } & \multirow{3}{*}{ Post } & Frequency & 254 & 112 & 118 & 51 & 535 \\
\hline & & $\%$ & $72.2 \%$ & $83.0 \%$ & $100 \%$ & $76.1 \%$ & $79.6 \%$ \\
\hline & & Residuals & -5.0 & 1.1 & 6.1 & -7 & \\
\hline & \multirow{3}{*}{$\begin{array}{c}\text { Comment } \\
\text { on post }\end{array}$} & Frequency & 1 & 7 & 0 & 0 & 8 \\
\hline & & $\%$ & $0.3 \%$ & $5.2 \%$ & $0 \%$ & $0 \%$ & $1.2 \%$ \\
\hline & & Residuals & -2.3 & 4.8 & -1.3 & -9 & \\
\hline & \multirow{3}{*}{$\begin{array}{l}\text { Response to } \\
\text { user comment }\end{array}$} & Frequency & 97 & 16 & 0 & 16 & 129 \\
\hline & & $\%$ & $27.6 \%$ & $11.9 \%$ & $0 \%$ & $23.9 \%$ & $19.2 \%$ \\
\hline & & Residuals & 5.8 & -2.4 & -5.8 & 1.0 & \\
\hline \multirow{2}{*}{\multicolumn{2}{|c|}{ Total }} & Frequency & 352 & 135 & 118 & 67 & 672 \\
\hline & & $\%$ & $100 \%$ & $100 \%$ & $100 \%$ & $100 \%$ & $100 \%$ \\
\hline
\end{tabular}

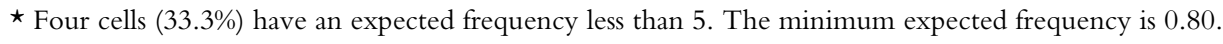


The People's Party both posts and responds to users' comments more than any other party. PSOE and Podemos are in a distant second and third place, respectively, with a similar number of posts. In last place, Ciudadanos has the smallest number of both posts and responses. The results of the Fisher's exact test indicate that the differences among categories are statistically significant $[F(6, \mathrm{n}=672)=87.95, p<.001]$.

The adjusted standardized residuals analysis indicates some statistical differences between the distinct types of posts. First, it is noteworthy that Podemos did not publish any comments or responses, causing the number of original posts to be statistically greater than the expected value $(Z=6.1)$. Second, the PP published a statistically high number of responses $(Z=5.8)$. Lastly, the PSOE posted comments at a significantly higher level than expected $(Z=4.8)$.

Regarding the subject matter of the parties' posts, we performed a hierarchical conglomerate test of the 12,708 words used in the 535 posts to establish the cooccurrences in each party's lexicon. Figure 1 shows the similarity index of the parties' words in their Facebook page posts. The dendrogram shows two blocks based on the co-occurrence of the words used, one formed by PP and PSOE $(J=.44)$ and the other by Podemos and Ciudadanos $(J=.28)$ Thus, we have found the similarity of the posts' subject matter to be related to how long the party has existed, with a marked similarity between the traditional parties' posts.

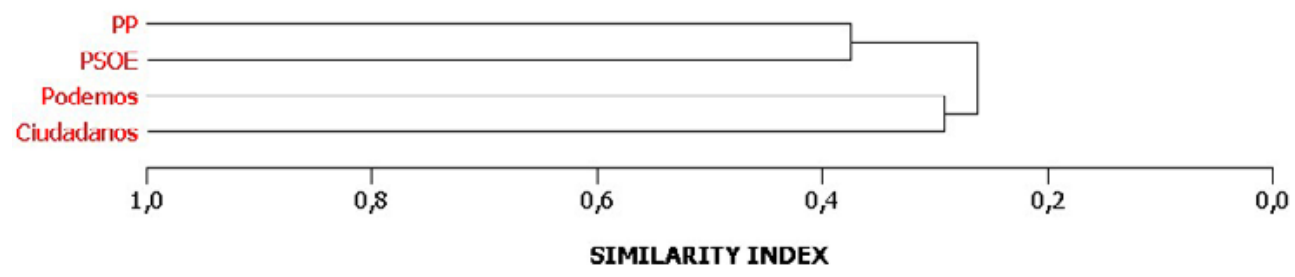

Source: prepared by the authors.

Figure 1

Similarity index of words used in posts, per party

Figure 2 shows the key word conglomerates map, in which the size of clusters is linked to how frequently a term appears and spatial proximity is linked to the terms' proximity to one another in posts. The map confirms the presence of two blocks: on the right are the words most used by the traditional parties (vote, platform, Spaniards, and links to live streamed campaign events), and on the left are the words most used by the emergent parties (hope, future, change, and details about where campaign events will take place). 
Nonetheless, a thorough analysis reveals differences in the subject matter of the parties' posts. While PSOE and Ciudadanos mention only their respective candidates, PP and Podemos repeatedly refer to the other parties' leaders, such as Podemos's Íñigo Errejón, and the PP's Javier Maroto, Pablo Casado, and María Dolores de Cospedal.

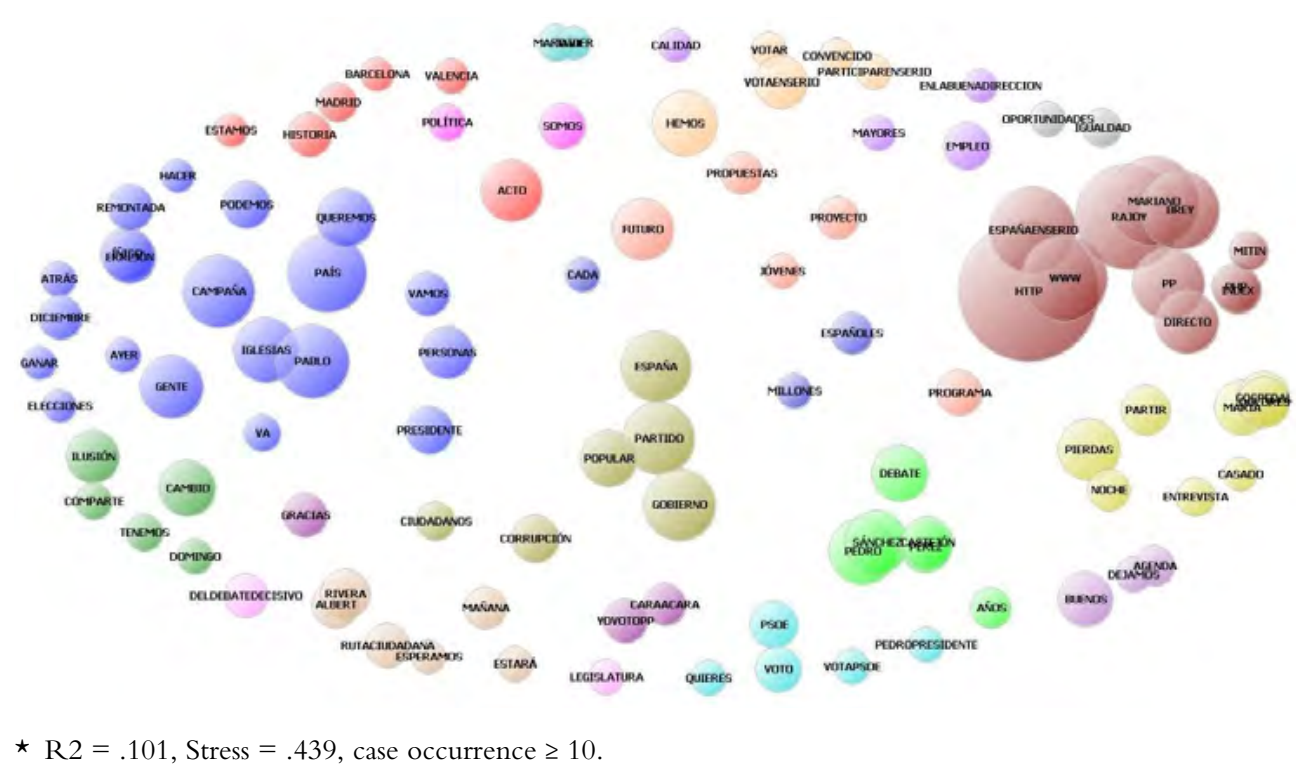

FiguRE 2

Concept map of key words on parties’ Facebook pages ${ }^{\star}$

As a result of posting more, the PP's posts also address more issues. In addition to promoting their candidate, mentioned in $29.13 \%$ of posts, the PP's Facebook page also promotes the party's official web page in $25.98 \%$ of posts. The party's posts also link the PP (then the majority in parliament) with the Spanish Government $(11.02 \%)$, ask people to vote for the party with the hashtag \#VotaEnSerio (vote seriously) (9.84\%), and mention María Dolores de Cospedal (9.84\%), streaming of live campaign rallies $(8.27 \%)$, candidate debates $(5.51 \%)$, as well as several topics from their political agenda, such as employment $(5.12 \%)$ and corruption $(2.36 \%)$. The PP's posts mention other parties' candidates, especially to criticize the PSOE candidate $(2.36 \%)$ for his proposed three-party coalition and the deficit left by the previous socialist government.

The PSOE's Facebook page focuses on the party's candidate, Pedro Sánchez (28.57\%), and on the PP's candidate's unfulfilled promises (17.86\%). The third-most used word in the PSOE posts is vote (13.39\%), followed by the party's hashtags 
(10.71\%) \#PedroPresidente and \#VotaPSOE, and references to the party's platform $(8.93 \%)$, equality $(8.04 \%)$, and education $(7.14 \%)$. The party also links to its webpage $(5.36 \%)$ and to streaming content $(4.46 \%)$.

Podemos promotes its candidate, Pablo Iglesias, in 30.51\% of its Facebook posts. Not far behind, the party uses words from its campaign slogans, such as country $(27.97 \%)$ and people $(22.03 \%)$. The party mentions its second-in-command, Íñigo Errejón, in $21.86 \%$ of its posts. The politician is followed by the words campaign (16.95\%), future (16.95\%), comeback (11.86\%), hope (9.32\%), change (8.47\%), and corruption (5.93\%). Unlike PP and PSOE, Podemos does not mention the other parties' candidates.

Lastly, Ciudadanos highlights its candidate, Albert Rivera, in 35.29\% of its posts, more than any other party. Rivera is followed by the hashtag \#RutaCiudadana (Citizen Way) (35.19\%) and the words hope (27.45\%), campaign (25.49\%), shares $(19.61 \%)$, change $(15.69 \%)$, country $(7.84 \%)$, corruption $(5.88 \%)$, and future $(5.88 \%)$ Like Podemos, Ciudadanos refrains from mentioning the other candidates in its posts, except for one brief message of support to Mariano Rajoy after the PP candidate was physically attacked during a campaign rally.

In addition to the content analysis of the words most used by the parties, we also performed a deeper analysis using the LIWC dictionary categories to identify any differences in the posts' and comments' emotional weight, how the parties address the users, and the verb tenses used to frame their messages. Table 2 shows the mean and the standard deviation of the words that express negative emotions, positive emotions, and the first-person plural in the four parties' posts, comments and responses. To identify any significant differences among the parties, we performed a one-way ANOVA test for each party, establishing the dictionary's three categories as the independent variables.

\section{TABLE 2}

Mean and standard deviation of each party for words with negative emotions, positive emotions, and first-person plural pronouns

\begin{tabular}{|c|c|c|c|c|c|c|c|c|}
\hline & \multicolumn{8}{|c|}{ Party } \\
\hline & \multicolumn{2}{|c|}{$\mathrm{PP}$} & \multicolumn{2}{|c|}{ PSOE } & \multicolumn{2}{|c|}{ Podemos } & \multicolumn{2}{|c|}{ Ciudadanos } \\
\hline & $M$ & $\mathrm{SD}$ & $M$ & $\mathrm{SD}$ & $M$ & $\mathrm{SD}$ & $M$ & $\mathrm{SD}$ \\
\hline Negative emotions & 0.19 & 0.49 & 0.13 & 0.39 & 0.19 & 0.54 & 0.07 & 0.26 \\
\hline Positive emotions & 0.72 & 0.93 & 0.70 & 1.04 & 1.08 & 1.10 & 1.13 & 1.27 \\
\hline We/us & 0.22 & 0.46 & 0.31 & 0.74 & 0.63 & 0.83 & 0.54 & 0.68 \\
\hline
\end{tabular}

Source: prepared by the authors. 
The limited number of words with negative emotions in the parties' publications indicate that the campaign transpired without much animosity. The variance analysis results are significant $[F(3,243.11)=3.15, p=.026]$, though the post hoc Games-Howell test only found significant differences $(p=.024)$ between the negative emotions used by PP $(M=0.19)$ and those used by Ciudadanos $(M=0.07)$

For positive emotions, too, the ANOVA test yields a significant result $[F(3,668)=6.42, p<.001]$. An analysis of the results of the Scheffe post hoc test reveals that the differences between the means of words with positive emotional weight used by the traditional parties are statistically smaller than those used by the emergent parties. Podemos and Ciudadanos ran positive campaigns, reflected in a greater number of words with positive emotions.

The difference in the use of words reflecting the first-person plural (we, us, our, etc. $)$ is also significant $[F(3,188.21)=12.21, p>.001]$. Here, the GamesHowell test also confirms differences between the traditional and emergent parties. As shown in Table 2, Podemos and Ciudadanos use the we for addressee or third party (Huddleston and Pullum, 2002) significantly more often than PP and PSOE.

\section{Conclusions}

Facebook is an extremely important channel for modern online political communication, as it one of the social networks most used to encourage participation in election campaigns (Williams \& Gulati, 2009). Politicians and candidates use the platform to create their digital image (Levonian, 2016), thereby wresting power from the intermediaries (Karlsen, 2015). Moreover, these platforms are an indispensable tool for groups lacking representation in parliament or sufficient media impact to reach the mass media audience.

Nonetheless, our study shows that the traditional majority parties published the most posts in the 2015 election campaign, in line with studies conducted in a similar period (Ballesteros et al., 2017). These results differ from those obtained in previous studies, in which candidates and parties with the greatest representation in parliament were the least active on social networks during the campaign for prime minister (Gamir et al., 2017; Larsson, 2016; Rúas-Araújo, Puentes-Rivera, \& Míguez-González, 2016). It seems the pressure exerted by minority parties and their pre-eminence on social networks has spurred the election machines of the major parties to evolve and incorporate these new channels into their communication strategies. On the same token, we have detected an emerging trend in the heads of party lists' social networks activity during the 2015 campaign: major party politicians made a greater than average number of Facebook posts (Gamir et al., 2017). 
Additionally, the results reflect differences in how the parties interact with the citizenry on social networks. Whereas the older parties dedicate part of their social networks activity to interacting with the citizenry, emergent parties, like Podemos, mostly use Facebook as a channel to spread their messages directly, and not as a tool to interact with supporters. As Jackson and Lilleker point out: "Political parties still seek to a significant extent to control the communication process and to inform rather than interact" (2009: 247). Thus, the level of interaction with users depends on the strategy of each party (Kalsnes, 2016), and the interactive potential of social networks may end up diluted in a colonization of the new digital communication spaces for electoral purposes (Lilleker \& Jackson, 2010).

Our content analysis of the posts, in keeping with a Twitter-focused study of the same campaign (López-García, 2016), shows differences stemming from the parties' age. First, the traditional parties pay more attention to their campaign platform, as seen on Twitter during the 2011 General Elections (Zamora \& Zurutuza, 2014). Second, the new parties emphasize the leader figure and run positive campaigns that heavily use the we for addressee or third party to engage users emotionally, as also pointed out by Abejón et al. (2017) in a qualitative analysis of the same elections. Previous studies had already found that Podemos's Facebook discourse in the 2014 European Elections heavily featured positive emotions and first-person plural pronouns (Sampietro \& Valera, 2015). Thus, given that Spanish political parties use Facebook differently depending on how long they have existed, both in terms of how they craft their messages and how they engage with citizens on their Facebook walls, we can accept the foundational hypothesis of our research.

Regarding our study's limitations, although using computer-assisted content analysis programs can reduce the rich detail found in human codification, we hold that the reproducibility of results and the ability to codify copious amounts of information justify using such programs in the study of online political communication. Nonetheless, we should point out several restrictions when extrapolating from our study's results. For example, our research focuses on the Facebook messages published by political parties and does not examine the posts made by candidates or messages published on other platforms. Additionally, the period of study is limited to the campaign. Consequently, we cannot speak to the nature of messages published beyond the context of the elections. Future studies should examine more cross-sectional and longitudinal corpora to determine if these differences are maintained throughout time and on other social networks.

Finally, the lower activity of emerging parties on Facebook may be due to a communicative strategy that seeks to obtain greater visibility in the media and bets on the use of Twitter, because the media pay more attention to this network (Abejón et al., 2017: 137). In addition, the larger budget of the majority parties can explain the publication of a greater number of posts and a higher 
level of interaction with the users of its pages, as suggested by the fact that the PP invests 290,000 $€$ for the Facebook campaign of the 2016 elections ${ }^{1}$. In this sense, in all the provinces where the Facebook ads were focused, the PP took the deputy in dispute with Ciudadanos. Future research should incorporate qualitative techniques, such as interviews with campaign teams in social networks, to confirm these hypotheses.

\section{References}

Abejón, P., Tejedor, L., Gómez Patiño, M., Risueño, I., Osuna, C., and Dader, J. L. (2015). El uso de webs, Facebook y Twitter en la comunicación electoral española de 2015: una mirada impresionista. In J. L. Dader and E. Campos (coords.), La búsqueda digital del voto. Cibercampañas Electorales en España 2015-16 (pp. 11-73). Valencia: Tirant lo Blanch.

Alashri, S., Kandala, S. S., Bajaj, V., Ravi, R., Smith, K. L., and Desouza, K. C. (2016). An analysis of sentiments on facebook during the 2016 US presidential election. In 2016 IEEE/ACM International Conference on Advances in Social Networks Analysis and Mining (ASONAM), San Francisco, USA, August 2016 (pp. 795-802). San Francisco: IEEE.

Aldrich, J. H., Gibson, R. K., Cantijoch, M., and Konitzer, T (2016). Getting out the vote in the social media era: Are digital tools changing the extent, nature and impact of party contacting in elections?. Party Politics, 22(2): 165-178. Doi: 10.1177/1354068815605304

Al-Rawi, A. (2017). News values on social media: News organizations' Facebook use. Journalism, 18(7), 871-889. Doi: 10.1177/1464884916636142

Bae, Y., and Lee, H. (2012). Sentiment analysis of Twitter audiences: Measuring the positive or negative influence of popular twitterers. Journal of the American Society for Information Science and Technology, 63(12), 2521-2535. Doi: 10.1002/asi.22768

Ballesteros, C. A., Zamora, R., Goulart, M., Sánchez, P., Gil, A., Díez, M., \& Muñiz, C. (2017). La interacción entre candidatos, partidos y ciudadanos en Facebook durante la campaña de las elecciones generales de 2015. Un análisis cuantitativo. In J. L. Dader, and E. Campos (coords.), La búsqueda digital del voto: cibercampañas electorales en España 2015-2016 (pp. 141-194). Valencia: Tirant lo Blanch.

Bode, L. (2017). Closing the gap: gender parity in political engagement on social media. Information, Communication \& Society, 20(4): 587-603. Doi: 10.1080/1369118x.2016.1202302

Bruns, A., and Burgess, J. (2012). Researching news discussion on Twitter: New methodologies. Journalism Studies, 13(5-6), 801-814. Doi: 10.1080/1461670X.2012.664428

Casero-Ripollés, A., Feenstra, R. A., and Tormey, S. (2016). Old and New Media Logics in an Electoral Campaign: The Case of Podemos and the Two-Way Street Mediatization of Politics. The International Journal of Press/Politics, 21(3), 378-397. Doi: $10.1177 / 1940161216645340$

\footnotetext{
1 http://www.elmundo.es/cronica/2016/07/03/57779fc0ca4741301d8b4609.html
} 
Caton, S., Hall, M., and Weinhardt, C. (2015). How do politicians use Facebook? An applied Social Observatory. Big Data \& Society, 2(2). Doi: 10.1177/2053951715612822

Conway, B. A., Kenski, K., and Wang, D. (2015). The rise of Twitter in the political campaign: Searching for intermedia agenda-setting effects in the presidential primary. Journal of Computer-Mediated Communication, 20(4), 363-380. Doi: 10.1111/ jcc4.12124

Dader, J. L. (2017). Campañas políticas “online”: La realidad española frente al horizonte internacional del "tecnocabildeo". In J. L. Dader, and E. Campos (coords.), La búsqueda digital del voto. Cibercampañas Electorales en España 2015-16 (pp. 75-140). Valencia: Tirant lo Blanch.

Davalos, S., Merchant, A., Rose, G. M., Lessley, B. J., and Teredesai, A. M. (2015). "The good old days": An examination of nostalgia in Facebook posts. International Journal of Human-Computer Studies, 83, 83-93. Doi: 10.1016/j.ijhcs.2015.05.009

Fenoll, V., García-Ull, F., and Rodríguez-Ballesteros, P. (2016). Valoración de candidatos en Twitter durante procesos electorales. El caso de las elecciones autonómicas valencianas de 2015. In Proceedings of the V Congreso Iberoamericano de Comunicación "Comunicación, Cultura and Cooperación”, Madrid, July 2016, pp. 595-605. Madrid: AE-IC. http://www.madrid2016.org/wp-content/uploads/aeic2016madrid_comunicaciones_ vdef_ok.pdf

Fernández-Cabana, M., Rúas-Araújo, J., and Alves-Pérez, M. T. (2014). Psychology, language and communication: Analysis with the tool LIWC of the speeches and tweets from the candidates to 2012 Galician elections. The UB Journal of psychology, 44(2), 169-184.

Gamir, J. (2016). Blogs, Facebook and Twitter en las elecciones generales de 2011. Estudio cuantitativo del uso de la web 2.0 por parte de los cabezas de lista del PP and del PSOE. Dígitos. Revista de comunicación digital, 2, 101-120. http://revistadigitos.com/ index.php/digitos/article/download/53/23

Gamir, J., Cano-Orón, L., and Calvo, D. (2017). La campaña electoral de 2015 en cifras. La presencia en la blogosfera, Facebook and Twitter de los cabezas de lista provinciales de PP, PSOE, Podemos and Ciudadanos. In G. López, and L. Valera (eds.), Pantallas electorales. El discurso de partidos, medios y ciudadanos en la campaña de 2015 (pp. 41-58). Barcelona: Editorial UOC.

Groshek, J., and Al-Rawi, A. (2013). Public sentiment and critical framing in social media content during the 2012 US presidential campaign. Social Science Computer Review, 31(5), 563-576. Doi: 10.1177/0894439313490401

Haro-de-Rosario, A., Sáez-Martín, A., and Caba-Pérez, M. C. (2016). Using social media to enhance citizen engagement with local government: Twitter or Facebook?. New Media E Society, 20(1), 29-49. Doi: 10.1177/1461444816645652

Huddleston, R., and Pullum, G. K. (2002). The Cambridge Grammar of the English Language. Cambridge, England: Cambridge University Press.

Kalsnes, B. (2016). The social media paradox explained: comparing political parties” Facebook strategy versus practice. Social Media E Society, 2(2). Doi: 10.1177/2056305116644616 
Karlsen, R. (2015). Followers are opinion leaders: The role of people in the flow of political communication on and beyond social networking sites. European Journal of Communication, 30(3), 301-318. Doi: 10.1177/0267323115577305

Keyling, T., and Jünger, J. (2013). Facepager. An application for generic data retrieval through APIs. Source code available from https://goo.gl/CCKaZY

Koc-Michalska, K., Lilleker, D. G., Smith, A., and Weissmann, D. (2016). The normalization of online campaigning in the web. 2.0 era. European Journal of Communication, 31(3), 331-350. Doi: 10.1177/0267323116647236

Larsson, A. O. (2016). Online, all the time? A quantitative assessment of the permanent campaign on Facebook. New Media \& Society, 18(2), 274-292. Doi: $10.1177 / 1461444814538798$

Larsson, A. O., and Kalsnes, B. (2014). "Of course we are on Facebook": Use and non-use of social media among Swedish and Norwegian politicians. European Journal of Communication, 29(6), 653-667. Doi: 10.1177/0267323114531383

Levonian, R. M. (2016). Personal and Group Identity in Facebook Political Posts. Philologica Jassyensia, 1(23), 223-231 https://goo.gl/wzxCN3

Lilleker, D. G., \& Jackson, N. A. (2010). Towards a more participatory style of election campaigning: The impact of Web 2.0 on the UK 2010 general election. Policy $\mathcal{E}$ Internet, 2(3), 69-98. Doi: 10.2202/1944-2866.1064

Lin, H., and Qiu, L. (2013). Two sites, two voices: Linguistic differences between facebook status updates and tweets. In International Conference on Cross-Cultural Design, Las Vegas, USA, 21-26 July 2013, pp. 432-440. Heidelberg: Springer. Doi: 10.1007/978-3-64239137-8_48

López-García, G. (2016). "New” vs "old” leaderships: the campaign of Spanish general elections 2015 on Twitter. Communication \& Society, 29(3), 149-168. Doi: 10.15581/003.29.3.149-168

Nitschke, P., Donges, P., and Schade, H. (2016). Political organizations" use of websites and Facebook. New Media \& Society, 18(5), 744-764. Doi: 10.1177/1461444814546451

Pennebaker, J. W., Booth, R. J., Boyd, R. L., and Francis, M. E. (2015). Linguistic Inquiry and Word Count: LIWC 2015. Austin, USA: Pennebaker Conglomerates. https://goo. $\mathrm{gl} / \mathrm{gn} 3 \mathrm{XPW}$

Provalis Research (2017). WordStat, Versión 7. https://goo.gl/MABDG0

Puentes-Rivera, I., Rúas-Araújo, J., and Dapena-González, B. (2017). Candidatos en Facebook: del texto a la imagen. Análisis de actividad and atención visual. Dígitos. Revista de Comunicación Digital, 3(1), 51-94. https://revistadigitos.com/index.php/digitos/ article/view/81

Rúas-Araújo, J., Puentes-Rivera, I., and Míguez-González, M. I. (2016). Capacidad predictiva de Twitter, impacto electoral and actividad en las elecciones al Parlamento de Galicia: un análisis con la herramienta LIWC. Observatorio (OBS*) Journal, 10(2), 55-87. Doi: 10.15847/obsOBS1022016893

Sampietro, A., and Valera, L. (2015). Emotional Politics on Facebook. An Exploratory Study of Podemos" Discourse during the European Election Campaign 2014. Recerca, Revista de pensament $i$ anàlisi, 17, 61-83. Doi: 10.6035/recerca.2015.17.4 
Stieglitz, S., and Dang-Xuan, L. (2012) Political communication and influence through microbloggi.ng. An empirical analysis of sentiment in Twitter messages and retweet behavior. In System Science (HICSS), 2012 45th Hawaii International Conference on, Maui, USA, 4-7 January 2012, pp. 3500-3509. IEEE. Doi: 10.1109/hicss.2012.476

Tan, P., Steinbach, M., and Kumar, V. (2006) Introduction to data mining. Boston, USA: Addison-Wesley.

Tumasjan, A., Sprenger, T. O., Sandner, P. G., and Welpe, I. M. (2010) Predicting elections with twitter: What 140 characters reveal about political sentiment. ICWSM, 10(1): 178-185.

Vaccari, C., and Valeriani, A. (2016) Party campaigners or citizen campaigners? How social media deepen and broaden party-related engagement. The International Journal of Press / Politics, 21(3), 294-312. Doi: 10.1177/1940161216642152

Valera, L., Sampietro, A., \& Fenoll, V. (2017). El debate ciudadano en redes sociales: ¿libertad o intimidación?. In G. López, and L. Valera (eds.), Pantallas electorales. El discurso de partidos, medios y ciudadanos en la campaña de 2015 (pp. 193-205). Barcelona: Editorial UOC.

Valeriani, A., and Vaccari, C. (2016) Accidental exposure to politics on social media as online participation equalizer in Germany, Italy, and the United Kingdom. New Media E Society, 18(9), 1857-1874. Doi: 10.1177/1461444815616223

Williams, C. B., and Gulati, G. J. (2009) Facebook grows up: An empirical assessment of its role in the 2008 congressional elections. In Proceedings from Midwest Political Science Association, Chicago, 2-5April 2009. Midwest Political Science Association.

Zamora, R., and Zurutuza, C. (2014). Campaigning on Twitter: Towards the "Personal Style" Campaign to Activate the Political Engagement During the 2011 Spanish General Elections. Communication \& Society, 27(1), 83-106. https://www.unav.es/fcom/ communication-society/es/articulo.php?art_id=481 